\title{
Composite Manufacturing Company: A Financial (MIS) Statement Case
}

\author{
John W. Kostolansky, Loyola University Chicago, USA \\ Brian B. Stanko, Loyola University Chicago, USA \\ Ellen L. Landgraf, Loyola University Chicago, USA \\ Michael D. Pakter, Gould \& Pakter Associates, LLC, USA
}

\begin{abstract}
Composite Manufacturing is a thriving privately-held company, whose owners need to attract outside investors. Composite's financial statements have not been professionally prepared nor audited. Although there is no fraud or intentional wrongdoing, the inexperience of the owners and their bookkeeper has resulted in improper financial reporting. In this case students will have to identify and restate revenues, expenses, assets, liabilities, and retained earnings in so far as they are not reported in accord with generally accepted accounting principles. Students are provided with a "Student Adjustment Template" and a "Student Worksheet Template" that allow them to make correcting entries in an organized manner as well as make subsequent changes to the financial statements. Instructors will be provided with teaching notes, a "Student Adjustment Template Solution" and a "Student Worksheet Template Solution" upon contacting the authors.
\end{abstract}

Keywords: financial reporting, financial restatement, revenue recognition, generally accepted accounting principles GAAP

\section{BACKGROUND}

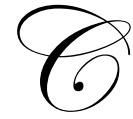

omposite Manufacturing ("Composite") is an innovator in the solar lighting field. The Company's only product is the "Sunpipe" - a highly reflective, maintenance free, natural light system that allows daylight to illuminate homes and offices. Daylight is reflected through the "Sunpipe" from a small rooftop dome to a translucent ceiling fixture, which magnifies and diffuses natural light into the room. The "Sunpipe's" revolutionary design efficiently reflects energy-free daylight from dusk to dawn at a fraction of the cost of electric lighting.

The Company is equally owned by two brothers, James and John Little. James is responsible for most corporate functions, overseeing credit, finance, sales, quality control and human resources. John is the plant manager and is in charge of production. The brothers developed and patented the "Sunpipe" in 1995 and incorporated the Company in 1998.

Sales have increased dramatically over the past two years, causing growing pains. After several unsuccessful attempts to borrow the needed funds, the Little brothers are seeking to sell 20 percent of the firm to outside investors. ${ }^{\text {i }}$ Consequently, the Company has asked its bookkeeper, Angel, to prepare a more complete set of financial statements to present to potential investors.

Angel acquired his bookkeeping skills while maintaining the accounting records for his father's farm. He obtained some free accounting software and is thoroughly familiar with using it. He also reviewed the financial reports of several publicly-traded companies' in an attempt to professionalize the appearance of the Composite Company's financial statements. 


\section{FINANCIAL REPORTING REQUIREMENTS}

Generally accepted accounting principles require revenues to be recognized when the earnings process has been completed and collection is reasonably assured. Specifically, Concepts Statement 5 (http://www.fasb.org/pdf/aop_CON5.pdf) states:

"Revenues and gains of an enterprise during a period are generally measured by the exchange values of the assets (goods or services) or liabilities involved, and recognition involves consideration of two factors, (a) being realized or realizable and (b) being earned... Revenues and gains are realized when products (goods or services), merchandise, or other assets are exchanged for cash or claims to cash. Revenues and gains are realizable when related assets received or held are readily convertible to known amounts of cash or claims to cash... [R] evenues are considered to have been earned when the entity has substantially accomplished what it must do to be entitled to the benefits represented by the revenues."

Expenses should be recorded in the same period as the revenue to which they are related. Losses should be recorded when it is probable that an impairment of asset value has occurred or that an obligation has been created. The Financial Accounting Standards Board wrote the following:

"Expenses and losses are generally recognized when an entity's economic benefits are used up in delivering or producing goods, rendering services, or other activities that constitute its ongoing major or central operations or when previously recognized assets are expected to provide reduced or no further benefits.

"An estimated loss from a loss contingency (as defined in paragraph 1) shall be accrued by a charge to income if both of the following conditions are met:

1. Information available prior to issuance of the financial statements indicates that it is probable that an asset had been impaired or a liability had been incurred at the date of the financial statements. It is implicit in this condition that it must be probable that one or more future events will occur confirming the fact of the loss.

2. The amount of loss can be reasonably estimated. ${ }^{i i}$

The general principle for revenue recognition is modified when customers are granted a right to return merchandise. In such situations, Statement of Financial Accounting Standards No. 48 (http://www.fasb.org/pdf/aop_FAS48.pdf) specifies that revenue can be recognized at the time of the sale only if the following six conditions are all met:

1. The seller's price to the buyer is substantially fixed or determinable at the date of sale.

2. The buyer has paid the seller, or the buyer is obligated to pay the seller and the obligation is not contingent on resale of the product.

3. The buyer's obligation to the seller would not be changed in the event of theft or physical destruction or damage of the product.

4. The buyer acquiring the product for resale has economic substance apart from that provided by the seller.

5. The seller does not have significant obligations for future performance to directly bring about resale of the product by the buyer.

6. The amount of future returns can be reasonably estimated... iii

\section{YOUR ROLE IN REVIEWING THE FINANCIAL STATEMENTS}

As an intern to a private equity firm that may buy a stake in Composite, you have been asked by the Director of New Business Development to perform a preliminary financial ratio analysis ${ }^{\text {iv }}$ of Composite. The ratios she has asked you to prepare include the following as shown in Table 1: 
Table 1

\begin{tabular}{|c|c|c|}
\hline Liquidity & Solvency & Profitability \\
\hline \multirow{6}{*}{$\begin{array}{l}\text { Current Ratio } \\
\text { Quick Ratio } \\
\text { Inventory Turnover } \\
\text { Days in Inventory } \\
\text { Receivables Turnover } \\
\text { Average Collection Period }\end{array}$} & Debt to Total Assets & \multirow{6}{*}{$\begin{array}{l}\text { Gross Profit Margin } \\
\text { Net Profit Margin } \\
\text { Return on Assets } \\
\text { Total Asset Turnover } \\
\text { Return on Equity }\end{array}$} \\
\hline & Debt to Equity & \\
\hline & Times Interest Earned & \\
\hline & & \\
\hline & Cash flow & \\
\hline & $\begin{array}{l}\text { Free Cash Flow } \\
\text { Cash Interest Coverage }\end{array}$ & \\
\hline
\end{tabular}

Once you complete your preliminary financial analysis, the Director would like you to proceed with a more thorough analysis of Composite's financial statements and the related notes to determine if Composite is properly reporting its financial position, operating performance, and cash flows in accord with generally accepted accounting principles. Although your work will be reviewed by one of the principals of the firm, you are aware that most successful accounting internships lead to full-time employment upon graduation. Thus, you are determined to independently conduct an impressive analysis of the situation.

The financial statements (Tables 2-4) and notes (Exhibit 1) prepared by Angel are presented on the next pages. In particular, you should review the notes to the financials to learn how Composite has recorded its revenues and expenses. Keep in mind that revenues affect not only the reported earnings on the income statement but also the amount of assets in the balance sheet. Expenses likewise have a dual effect on income and assets (or income and liabilities). As you are reading the notes, consider whether each item has been properly classified in the financial statements. Improper classification can affect a firm's financial ratios and your analysis. Review the notes carefully to determine the questionable accounting issues that require your attention. All correcting entries should be recorded in the Student Adjustment Template that follows the Ratio Analysis Information page.

Using the Student Worksheet Template provided in a Exhibit 2, enter the changes that must be made to Composite's financial statements (taken from your Student Adjustment Template) to bring them into conformity with generally accepted accounting principles. Once you prepare the revised set of financial statements, recalculate the financial ratios that you reported in step 1. Compare and contrast these measures of performance and use this information as a basis for your conclusion. When you complete your review, the following documentation should comprise your case study analysis:

1. A one-page business memo which includes your tentative recommendation as to whether or not your firm should buy a stake in Composite based upon your preliminary ratio analysis and other business risks. The preliminary ratio analysis is easily calculated on the Student Worksheet Template.

2. A succinct report (1-2 pages) outlining the areas of reporting concerns.

3. A revised set of financial statements as well as the recalculated financial ratios based upon your recommended correcting entries.

4. A statement summarizing the materiality of the financial misstatements.

5. A final recommendation on whether or not your firm should buy a stake in Composite.

Your firm is depending on you to review and revise (if necessary) the financial information provided by Composite. It is essential that you conduct your analysis using the correct amounts of revenues, expenses, assets, and liabilities. Only then can an informed decision be made. Even relatively small errors in financial reporting can lead to an incorrect decision and ultimately weaken your company's shareholder returns. 
Table 2

Composite Manufacturing

Balance Sheets at December 31

(all amounts in \$ thousands)

\begin{tabular}{|c|c|c|}
\hline Assets & 2008 & 2007 \\
\hline \multicolumn{3}{|l|}{ Current Assets } \\
\hline Cash & $\$ 14$ & $\$ 331$ \\
\hline Accounts receivable (net of allowance for doubtful & & \\
\hline accounts of $\$ 15,000$ for 2008 and 2007) & 1,149 & 1,125 \\
\hline Inventory (note 2) & 3,416 & 2,636 \\
\hline Due from affiliates (note 3 ) & 246 & 181 \\
\hline Other current assets (note 8) & 302 & 42 \\
\hline Total current assets & $\overline{5,127}$ & $\overline{4,315}$ \\
\hline Property, plant and equipment (net) (notes 4 and 6) & 766 & 680 \\
\hline Other assets & 107 & 59 \\
\hline Total assets & $\overline{\underline{\$ 6,000}}$ & $\underline{\$ 5,054}$ \\
\hline \multicolumn{3}{|l|}{ Liabilities And Stockholders Equity } \\
\hline \multicolumn{3}{|l|}{ Current liabilities } \\
\hline Accounts payable & $\$ 461$ & $\$ 494$ \\
\hline Current portion of long-term debt (note 5) & 1,566 & 1,141 \\
\hline Accrued expenses & 334 & 291 \\
\hline Estimated environmental cleanup (note 9) & 300 & - \\
\hline Total current liabilities & 2,661 & 1,926 \\
\hline Long-term Debt (note 5) & 645 & 606 \\
\hline Total liabilities & $\overline{3,306}$ & $\underline{2.532}$ \\
\hline \multicolumn{3}{|l|}{ Stockholders equity } \\
\hline Common stock & 2 & 2 \\
\hline Retained earnings & $\underline{2,692}$ & $\underline{2,520}$ \\
\hline Total stockholders equity & 2,694 & 2.522 \\
\hline Total liabilities and stockholders equity & $\$ 6,000$ & $\$ 5,054$ \\
\hline
\end{tabular}

Table 3

Composite Manufacturing

Income Statements for the Years Ended December 31

(all amounts in \$ thousands)

Net sales (note 7)

Cost of goods sold

Gross profit

Operating expenses

Shipping

Selling

General and administrative

Total operating expenses

\begin{tabular}{rr}
$\underline{\mathbf{2 0 0 8}}$ & $\underline{\mathbf{2 0 0 7}}$ \\
$\$ 9,750$ & $\$ 8,898$ \\
$\underline{6,121}$ & $\underline{5,711}$ \\
$\underline{3,629}$ & $\underline{3,187}$ \\
126 & 80 \\
636 & 446 \\
$\underline{1,829}$ & $\underline{1,604}$ \\
$\underline{2,591}$ & $\underline{2,130}$ \\
\hline
\end{tabular}

Other expenses

Interest expense

Estimated environmental cleanup costs (note 9)

Total other expenses

Earnings before state income taxes

Provision for state income taxes

567906


Table 4

Composite Manufacturing

Statements of Cash Flow for the Years Ended December 31 (all amounts in \$ thousands)

Cash flow from operating activities

Net income

Adjustments to reconcile net income to net cash provided by operating activities

(Increase) decrease in:

Accounts receivable (net)

Inventory

Other current assets

Other assets

Increase (decrease) in:

Accounts payable

Accrued expenses

Estimated environmental cleanup

Net cash provided (used) by operating activities

\section{8}

$\$ 554$

2007

Cash flows from investing activities

Purchase of equipment

Proceeds from the sale of fixed assets

Receivables from affiliate

Net cash used in investing activities

Cash flows from financing activities

Long-term borrowing (debt repayment)

Distributions to stockholders

Net cash provided (used) in financing activities

Net decrease in cash

Cash, beginning of year

Cash, end of year

70

$\underline{300}$

$\underline{(178)}$

(156)

$--$

$\frac{(65)}{(221)}$

$\frac{(65)}{(221)}$

\section{Supplemental disclosures:}

Interest paid

Income taxes paid

(317)

$\underline{331}$

$\$ 14$

829

$\$ \underline{\underline{\$ 31}}$

\begin{tabular}{rr}
$\mathbf{2 0 0 8}$ & $\mathbf{2 0 0 7}$ \\
$\$ 168$ & $\$ 137$ \\
17 & 22 \\
\hline
\end{tabular}

\section{EXHIBIT 1}

\section{Note 1 - Summary of Significant Accounting Policies and Business of the Company}

\section{Business of the Company}

The company manufactures and sells super reflective natural light systems within the United States and the European Economic Community.

\section{Estimates}

The preparation of the company's financial statements in conformity with generally accepted accounting principles requires management to make estimates and assumptions that reflect the reported amount of assets and liabilities and disclosure of contingent assets and liabilities at the date of the financial statements and reported amounts of revenues and expenses during the period. Actual results could differ from these estimates. 


\section{Accounts receivable}

Our accounts receivable includes accounts receivable reduced by an allowance for doubtful accounts. The allowance is based on historical experience as well as any known trends or uncertainties related to customer billing and account collectability. The adequacy of our allowance is reviewed quarterly.

In the first quarter of 2008 , the Company recorded sales of $\$ 167,000$ of light systems to Anjinu Design, a startup firm specializing in environmentally green building designs. Given the uncertainties inherent in startup businesses, the Company has required that Anjinu submit monthly reports of "Sunpipe" installations accompanied by payment for the systems sold. To date, Anjinu has not sold any systems and has not made any payments on the purchased light systems.

\section{Inventory}

Inventory is valued using the first-in, first-out method.

As a result of increased economic pressure, Composite negotiated a $20 \%$ volume discount on an end-of-year $\$ 100,000$ raw material purchase. The discount was recorded as revenue at the time of purchase.

\section{Property, plant, and equipment}

Property, plant, and equipment are stated at cost.

Depreciation is provided utilizing the straight-line method over estimated useful lives ranging from 5 to 40 years for buildings, 15 to 31.5 years for leasehold improvements, and 5 to 12 years for all other property and equipment.

\section{Income Taxes}

The company elected to be taxed as an "S" corporation under the Internal Revenue Code effective January 1, 1993. In lieu of corporate federal tax, the stockholders of an "S" corporation are taxed on their proportionate share of the corporation's income. However, the corporation is required to pay certain state income taxes.

\section{Note 2 - Inventory}

Inventory consists of the following as shown in Table 5:

(Amounts in $\$$ thousands)

Table 5

\begin{tabular}{|l|c|c|}
\hline & $\underline{\mathbf{2 0 0 8}}$ & $\underline{\mathbf{2 0 0 7}}$ \\
\hline Raw materials & $\$ 539$ & $\$ 463$ \\
\hline Finished goods & $\underline{2,877}$ & $\underline{2,173}$ \\
\hline Total & $\underline{\underline{3,416}}$ & $\underline{2,636}$ \\
\hline
\end{tabular}

At the close of 2008, $\$ 50,000$ of raw material was left in an unheated storage area of Composite's warehouse. The raw material was unsalvageable, could not be used in the manufacturing process, and subsequently was omitted from the year end physical inventory count.

\section{Note 3 - Related party transactions}

In December, 2008, the Company sold to its affiliate $\$ 246,000$ of "Sunpipe" systems, which were subsequently returned in February. The Company included \$246,000 as Amount Due from Affiliate and in Net Sales for 2008. The affiliated company is controlled by the Company's shareholders.

See Note 6 for lease with related party. 


\section{Note 4 - Property, plant, and equipment}

Property, plant, and equipment consist of the following as shown in Table 6:

(Amounts in \$ thousands)

Table 6

\begin{tabular}{|l|c|c|}
\hline & $\underline{\mathbf{2 0 0 8}}$ & $\mathbf{2 0 0 7}$ \\
\hline Land & $\$ 44$ & $\$ 43$ \\
\hline Land improvements & 40 & 40 \\
\hline Buildings & 899 & 892 \\
\hline Leasehold improvements & 109 & 109 \\
\hline Machinery and equipment & 364 & 355 \\
\hline Furniture and fixtures & 112 & 108 \\
\hline Computer equipment & 40 & $\underline{61}$ \\
\hline Automobiles & $\underline{147}$ & 1,711 \\
\hline Total cost & 1,755 & $\underline{1,031}$ \\
\hline Less: accumulated depreciation & $\underline{\$ 89}$ & $\underline{\underline{9680}}$ \\
\hline Net property, plant, and equipment & $\underline{\underline{\$ 766}}$ & \\
\hline
\end{tabular}

\section{Note 5 - Long-term Debt}

Long-term debt consists of the following as shown in Table 7 (Amounts in $\$$ thousands):

Table 7

\begin{tabular}{|l|c|c|}
\hline & $\underline{\mathbf{2 0 0 8}}$ & $\underline{\mathbf{2 0 0 7}}$ \\
\hline $\begin{array}{l}\text { Revolving line of credit, interest payable monthly at prime; principal plus accrued interest } \\
\text { due on October 1, 2011, collateralized by substantially all the assets of the Company, } \\
\text { guaranteed by the stockholders }\end{array}$ & $\$ 2,211$ & $\$ 1,747$ \\
\hline Less current portion & $\underline{1,566}$ & $\underline{\mathbf{\$ 6 4 5}}$ \\
\hline Long-term debt & $\underline{\underline{\$ 606}}$ \\
\hline
\end{tabular}

\section{Note 6 - Commitments}

The Company leases its warehouse facilities in Miami, Florida from an entity controlled by the Company's stockholders. The lease expires April 30, 2011. Rent expense aggregated $\$ 105,394$ and $\$ 100,963$ for the years ended December 31, 2008 and 2007 respectively.

In 2005, the Company entered into an agreement to sublease a portion of its warehouse. The terms of the sublease require monthly payments of $\$ 3,600$ through April 30, 2011. The subleased portion of the warehouse contains $\$ 109,000$ of leasehold improvements which are not being utilized by the lessee. Consequently, the company has ceased depreciating the improvements. The sublease rental income is reflected as a reduction of rent expense.

\section{Note 7 - Litigation}

In May, 2008, the Company received a $\$ 1,000,000$ settlement of its patent infringement claim against Sunburst Solar Tubes, bringing a five-year lawsuit to a close and strengthening the Company's patent. The settlement amount was included in sales revenue.

\section{Note 8 - State Grants}

In October, 2008, Composite applied to the State of Illinois for a grant to develop "Sunpipe" systems for several state and city government buildings. The State of Illinois Grant Board acknowledged receipt of the grant request in the amount of $\$ 255,000$ and has begun processing the request. Composite has recorded a sale and an Other Current 
Asset for $\$ 255,000$.

Note 9 - Contingencies

The Company is the defendant in a $\$ 4,000,000$ product liability suit arising from the explosion of translucent light fixtures. The Company's fault in the matter is not being contested. Although the Company carries adequate liability insurance, there is a $\$ 500,000$ deductible on the policy. A court decision is expected in early 2009 . It is the Company's policy to delay recognition of lawsuit settlements until cases have been decided.

The Company is in negotiations with the Environmental Protection Agency regarding fines and cleanup costs at one of Composite's factory sites. Final EPA estimates range between $\$ 300,000$ and $\$ 500,000$. The Company recorded a provision for $\$ 300,000$ against 2008 income.

\section{Note 10 - Service Agreements}

In 2008, the Company began selling 3-year service contracts on the "Sunpipe" product. While the product is considered to be maintenance free, an annual inspection of the refractor is required after one year to maintain operating efficiency. The Company sold 36 contracts at $\$ 3,000$ each during 2008 . The Company reported the proceeds as sales revenue since each service contract was associated with a unit sold.

\section{Ratio Analysis Information}

Note: Given the limited number of years of data for Composite, compute the turnover ratios and return on assets/equity ratios using the year-end balance for the related account, rather than the average of beginning and ending values. The definitions provided below are based upon year-end balances.

\section{Liquidity Ratios}

\section{Current Ratio: Current assets/Current liabilities}

Use: Like Working Capital, this is a measure used to determine the company's ability to pay its short-term debt; the ratio is useful not only to compare the company's liquidity over time, but also to compare its liquidity with that of competitors.

\section{Quick Ratio: Quick assets (cash, accounts receivable, short-term investments)} Current liabilities

Use: Stricter measure of ability to pay current liabilities as it includes only assets that are quickly and easily converted to cash.

\section{Inventory Turnover: $\quad$ Cost of goods sold} Ending inventory

Use: Estimates how many times in a year the inventory is sold (i.e., "turned over"). The faster a company can turn its inventory, the more efficient it is. Of course, a reasonable level of inventory must be maintained to optimize sales.

\section{Days Sales in Inventory (Number of days to sell inventory): 365/Inventory turnover}

Use: A measure of how many days, on average, it takes to sell inventory.

\section{Receivable Turnover: Sales/Ending accounts receivable}

Use: Estimates how many times in a year the accounts receivable are collected. The faster a company can turn its receivables, the more efficient it is. Of course, the goal is to turn receivables quickly without foregoing credit sales. 
Average Collection Period (Days to collect Accounts Receivable): 365/ Receivable turnover

Use: A measure of how many days, on average, it takes to collect accounts receivable.

Solvency Ratios

Debt to Total Assets: Total liabilities/Total assets

Use: Shows the proportion of assets financed with debt. The remainder of assets will have been proportionally financed with equity.

\section{Debt to Equity: Total liabilities/Total equity}

Use: An alternative for Debt to Total assets, this ratio shows the proportion of debt to equity.

Times Interest Earned: Earnings before interest and taxes (EBIT)/Interest expense

Use: Measures the company's ability to pay the interest on its debts; a high multiple is desirable.

Profitability

Gross Profit Margin: (Net sales - Cost of sales)/Net sales

Use: Measures the proportion of revenue available to cover operating expenses after deducting the cost of the merchandise sold.

Net Profit Margin: Net income/Net sales

Use: Measures the proportion of each dollar of sales that becomes net income.

Return on Assets: Net income/Ending total assets

Use: Measures the amount of income generated with each dollar of assets.

Total Asset Turnover: Sales/Ending total assets

Use: Measures the amount of sales revenue generated with each dollar of assets.

Return on Equity: Net income/Ending stockholders equity

Use: Measures the amount of income generated with each dollar of investment provided by shareholders.

Cash Flow

Free Cash Flow: Cash flow from operations - capital expenditures

Use: Measures the ability of the firm to sustain itself and possibly grow without outside funding.

Cash Interest Coverage: Cash flow from operations + Interest paid + taxes paid Interest paid

Use: Measures the adequacy of operating cash flows to cover interest payments. A high multiple is desirable. 


\section{Student Adjustment Template (to bring Composite's Financial Statements into Conformity with GAAP)}

Dear Student: Your adjustments should be in \$ thousands. Rely on the relationship between cost of goods sold and sales (i.e., CGS/Sales) to estimate the cost of goods sold adjustment associated with a sales adjustment. Specifically, estimate cost based upon

$$
\frac{\text { Cost of goods sold }}{\text { Sales }}=\frac{6,121}{9,750}=62.78 \%
$$

\section{Other Important Information}

Utilize (copy and paste) the following template (Exhibit 2) to prepare each correcting entry:

\section{EXHIBIT 2}

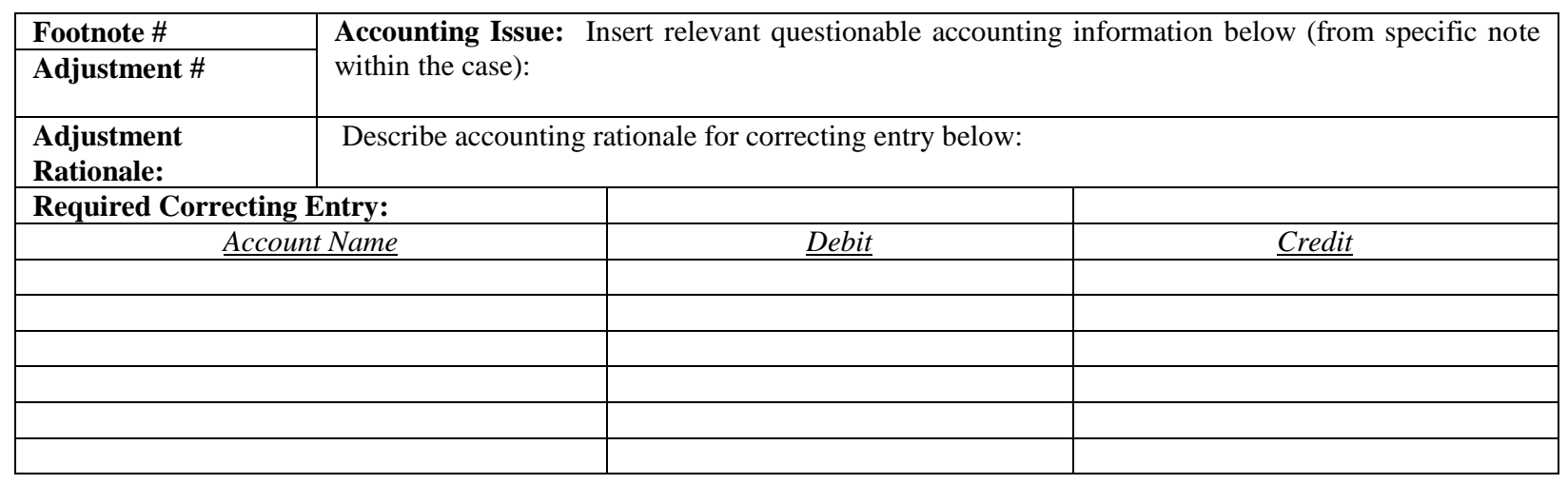

As you move forward, identify the accounting issue and the footnote number in which the issue arises. Number your adjustments to correspond with each correcting entry and record this information in the worksheet.

Once you complete the correcting entries, a 3-step process begins. First, review the correcting entries with your professor before moving on. Second, after you gain your professor's approval, return to the Student Worksheet Template to restate the financials. Once you complete the restatement, again review the results with your professor. Finally, if all is acceptable, re-compute the necessary financial ratios. Then move on and complete steps 4 and 5 of the following case requirements.

1. A one-page business memo which includes your tentative recommendation as to whether or not your firm should buy a stake in Composite based upon your preliminary ratio analysis and other business risks. The preliminary ratio analysis is easily calculated on the Student Worksheet Template.

2. A succinct report (1-2 pages) outlining the areas of reporting concerns.

3. A revised set of financial statements as well as the recalculated financial ratios based upon your recommended correcting entries using the Student Worksheet Template.

4. A statement summarizing the materiality of the financial misstatements.

5. A final recommendation on whether or not your firm should buy a stake in Composite.

Note: Do not attempt to complete this assignment without reviewing your results with your professor. Doing so can lead to a great deal of unnecessary work.

\section{TEACHING NOTES}

The Composite Manufacturing Company Case is in fact a composite of various characters and situations encountered by a practitioner over a period of years. The facts and circumstances have been modified and 
supplemented to provide an integrative case appropriate for students in an advanced course in accounting. In completing the case students will utilize their knowledge of financial reporting, financial statement analysis and generally accepted accounting principles coupled with critical thinking and written communication skills. The case was class tested in a graduate Forensic Accounting and Fraud course which had a prerequisite of an undergraduate course in auditing, and would be equally appropriate in an undergraduate upper level course or a graduate course in financial reporting or financial statement analysis. The teaching notes for the case include suggested solutions to each of the case requirements as well as comments based on the class test. All solutions and teaching notes as well as the "Student Adjustment Template Solution" and "Student Worksheet Template and Solutions" are available electronically from the authors.

\section{AUTHOR INFORMATION}

John W. Kostolansky holds a Ph.D. from Columbia University and a BBA from Loyola University Chicago. His research interests include financial statement analysis, financial reporting, and effective teaching methods. Graduate courses taught include Financial Accounting for Business Decisions, Issues in Financial Reporting and Financial Statement Analysis. He is a registered Certified Public Accountant (Illinois.)

Brian B. Stanko holds a Ph.D. from the University of Kentucky, and an MBA and a BS from Eastern Illinois University. He is a registered Certified Public Accountant (Illinois.) Dr. Stanko's work experience includes five years in accounting and financial reporting and twenty years in academia. His research interests are in the areas of cash flow analysis, annual report analysis, corporate reporting and accounting education. He currently serves as the Chair of the Accounting and Business Law Department at Loyola University Chicago.

Ellen L. Landgraf holds a Ph.D. from the University of Illinois at Chicago, an MBA from Northern Illinois University and a BBA from Loyola University Chicago. She is a registered Certified Public Accountant (Illinois.) Dr. Landgraf's work experience includes positions at the IRS and in public accounting (both Big Eight and small practitioner) prior to her over thirty years in academia. Her research interests are in the areas of executive compensation, corporate governance and social responsibility, corporate disclosure and reputation and ethics and accounting.

Michael D. Pakter is a licensed Certified Public Accountant, Certified in Financial Forensics by the American Institute of Certified Public Accountants, with more than 30 years experience in financial analysis. He has a Certified Insolvency and Restructuring Advisor Certificate and a Certification in Distressed Business Valuation. He is also a Chartered Accountant and a Certified Fraud Examiner. His undergraduate academic education is in commerce, business economics, accounting and auditing. Mr. Pakter is a Managing Member of Gould \& Pakter Associates, LLC.

\footnotetext{
${ }^{\mathrm{i}}$ Composite provided a set of summary financial statements to the lending institutions but these statements were not as complete, nor in the customary format as those normally provided to investors.

ii Accounting for Contingencies, Statement of Financial Accounting Standards No. 5 (Stamford, CT: Financial Accounting Standards Board, 2008), para. 8.

iii Revenue Recognition When Right of Return Exists, Statement of Financial Accounting Standards No. 48 (Stamford, CT: Financial Accounting Standards Board, 2008), para. 6.

iv See the Ratio Analysis Information page (follows the financial statements and related notes) for the ratio formulas. Occasionally, there may be a slight deviation in how a specific ratio is calculated, thus it is best if a standard model is incorporated in the analysis. As a result, use the formulas that are provided on this page.
} 


\section{NOTES}

